American Journal of Agricultural and Biological Sciences 4 (3): 179-186, 2009

ISSN 1557-4989

(C) 2009 Science Publications

\title{
Distribution of $\beta$-Glucosidase Activity within Aggregates of a Soil Amended with Organic Fertilizers
}

\author{
Saeid Hojati and Farshid Nourbakhsh \\ Department of Soil Sciences, College of Agriculture, \\ Isfahan University of Technology, Isfahan, 84156-83111, Iran
}

\begin{abstract}
Problem statement: Distribution pattern of enzyme activities in soil aggregate size classes as affected by organic amendments is not well understood. Approach: A study was conducted to evaluate the effects of repeated annual application of Cow Manure (CM), Sewage Sludge (SS) and Municipal Solid Waste Compost (MSW) on the distribution of $\beta$-Glucosidase $(\beta \mathrm{G})$ activity within aggregates of a soil. Soil samples were collected from $0-15 \mathrm{~cm}$ of a soil which, had been treated annually from 1999-2006 at 4 application rates with three replications. A control (with no application) was also run. Soil organic $C$ content and $\beta G$ activity were measured in 5 aggregate size fractions. Results: Results illustrated that application of the amendments decreased the proportion of microaggregates $(<0.25 \mathrm{~mm})$. The proportion ranged from $64 \%$ in control to $35 \%$ in MSW. In contrast, the proportion of macroaggregates $(>0.25 \mathrm{~mm}$ diameter) enhanced from $35 \%$ in control to $65 \%$ in MSW. Application of organic amendments modified the distribution of Soil Organic C (SOC) content and $\beta \mathrm{G}$ activity. Distribution of SOC in macroaggregate classes was not identical in CM, SS and MSW treatments. The distribution pattern of $\beta G$ activities in aggregate size classes was dissimilar to those of SOC contents. In general, an increasing trend was observed in $\beta G$ activity as the aggregate sizes increased. The highest level of $\beta \mathrm{G}$ activity was observed in aggregate size classes of $>2 \mathrm{~mm}$ of all applied soils. Among the solid waste treatments, $\mathrm{CM}$ induced greater $\beta \mathrm{G}$ activity in macroaggregates. For all aggregate size classes, the lowest level of $\beta G$ activity was observed in control. Conclusion/Recommendations: To conclude, organic fertilization increased the proportion of macroaggregates to microaggregates. The highest activities of $\beta G$ and SOC contents were observed in macroaggregates and in soils received the highest rates of organic fertilizer applications.
\end{abstract}

Key words: Soil enzymes, macroaggregates, microaggregates, organic amendments

\section{INTRODUCTION}

One of the characteristics of soils in arid and semiarid regions of the world is their scarcity of organic matter ${ }^{[1]}$. Organic matter is involved in the enhancement of soil quality since it acts on soil structure, nutrient storage and biological activity ${ }^{[2]}$. The application of organic fractions of urban wastes (e.g., sewage sludge and municipal solid wastes) as organic amendments to agricultural soils of these areas may be of use in improving their quality and be considered an attempt to alleviate the serious environmental and health problems caused by their accumulation ${ }^{[3]}$.

Aggregation and Soil Organic Carbon (SOC) concentrations represent integrative effects of soil type, environment and soil management practices including crop rotation, tillage and fertilizer management ${ }^{[4]}$. The SOC acts as a binding agent and as a nucleus in the formation of aggregates. The decline in soil structure is increasingly seen as a form of soil degradation and is often related to improper land use and soil/crop management practices ${ }^{[5]}$.

The position of Soil Organic Matter (SOM) within the soil matrix is an important determinant of its fate ${ }^{[6]}$. Nearly $90 \%$ of SOM was found to be located within soil aggregates ${ }^{[7]}$. Not only the distribution of total soil organic matter among the aggregate size fractions can be heterogeneous and is subject to variations, but also that of young vs. old organic matter ${ }^{[8]}$.

Few studies investigated relationships between aggregate formation and organic matter cycling under application of organic amendments and a better understanding is needed of how organic amendments may contribute to the enhancement of soil organic matter. Indeed, knowledge of the cycling and compartmentalization of soil $\mathrm{C}$ that influence $\mathrm{C}$ storage

Corresponding Author: Farshid Nourbakhsh, College of Agriculture, Isfahan University of Technology, Isfahan, 84156-83111, Iran 
may lead to the developments of the strategies to increase soil $\mathrm{C}$ storage potentials ${ }^{[9]}$.

There is currently great interest in the use of enzymes as biological indicators of soil quality, because they are relatively simple to determine, have microbial ecological significance, are sensitive to environmental stress and respond rapidly to changes in land management. Research has shown that $\beta$-glucosidase (EC 3.2.1.21) activity is the most abundant and easily detected of the three enzymes involved in cellulose degradation in soil, thus making it ideal to examine the importance of physico-chemical controls on the turnover of soil organic matter. Indeed, it provides an early indication of changes in organic matter status and turnover $^{[10]}$.

Changes in soil structural properties brought about by the use of organic amendments might change the interactions between microorganisms and their substrates in the soil matrix. We hypothesized that soil structural changes stimulated by application of organic amendments might be reflected in the size distribution of soil aggregates and might allow us to identify sites where highest level of activities exist. This study aims to identify physical locations within the soil structure that display the greatest amount of enzymatic activity under organic fertilization (Cow Manure (CM), Sewage Sludge (SS) and Municipal Solid Waste Compost (MSW).

\section{MATERIALS AND METHODS}

A field experiment was initiated in 1999 on a silty clay loam soil (Typic haplargid: Clay, $357 \mathrm{~g} \mathrm{~kg}^{-1}$; sand, $136 \mathrm{~g} \mathrm{~kg}^{-1}$; $\mathrm{pH}$ 8.3) in Lavark research station (32 $30^{\prime}$ $\left.\mathrm{N}, 51^{\circ} 20^{\prime} \mathrm{E}\right)$, Isfahan, Iran. The environmental conditions define the area as arid with an average annual rainfall of $140 \mathrm{~mm}$ and a mean annual temperature of $14.5^{\circ} \mathrm{C}$. Repeated annual applications of three organic fertilizers (CM, SS and MSW) at three levels of application $\left(25,50\right.$ and $100 \mathrm{Mg} \mathrm{ha}^{-1}$ ) were arranged in a complete block design with three replicates. A control treatment was also run. Soil sampling was performed in July 2006 at the end of the 7th year of application. Composite soil samples were collected from surface soils $(0-15 \mathrm{~cm})$. Soil Organic Carbon (SOC) was determined using wet digestion procedure on whole soil and on all aggregate size fractions ${ }^{[11]}$.

The wet sieving method used for aggregate distribution in this study was adapted from those described earlier ${ }^{[7]}$. The sieve sizes were $2,1,0.5,0.25$, $0.1 \mathrm{~mm}$; therefore, the size fractions collected were $>2$, $1-2,0.5-1,0.25-0.5$ and $0.1-0.25 \mathrm{~mm}$. The sieves were nested with the largest mesh on top and placed into a large basin. Distilled water was added to the basin until the water level reached $1 \mathrm{~cm}$ below the wire mesh of the $2 \mathrm{~mm}$ sieve. The soil (100 g dry weight) spread out evenly over the surface of the $2 \mathrm{~mm}$ mesh and then the water level rose just until the soil could be wet by capillarity. The soils were allowed to moisten for $10 \mathrm{~min}$. Sieving consisted of raising and lowering the nest of sieves $1 \mathrm{~cm}$ at a rate of $50 \mathrm{times} / \mathrm{min}$ for $2 \mathrm{~min}$. After sieving the soils were remained in the basin undisturbed for 5 min to allow fine particles to settle. Then the nest of sieves were slowly removed from the basin and paced onto a catch pan to collect any remaining water. The sieves were separated and allowed to dry and then aggregates of different sizes were collected from the sieves $^{[7]}$.

$\beta$-Glucosidase $(\beta G)$ activity was determined on whole soil and all aggregate size fractions according to an standard protocol ${ }^{[12]}$. In brief, $1 \mathrm{~g}$ samples of air-dried soil were incubated for $1 \mathrm{~h}$ with $\rho$-nitrophenyl $\beta$ - Dglucoside and toluene in a $\mathrm{pH} 6.0$ modified universal buffer and Product, $\rho$-nitrophenol (PNP), was determined colorimetrically at $420 \mathrm{~nm}$. $\beta$-glucosidase activity was reported as mg PNP $\mathrm{kg}^{-1}$ soil $\mathrm{h}^{-1}$ or $\mathrm{mg}$ PNP kg-1 aggregates $h^{-1}$.

Analysis Of Variance (ANOVA) and least significant difference (LSD, $\mathrm{p}<0.05)$ was determined by SAS 8.02 software $^{[13]}$.

\section{RESULTS}

Chemical characteristics of the organic amendments are summarized in Table 1 . The $\mathrm{pH}$ values were 6.4 in SS, 7.8 in MSW and 8.6 in CM. The electrical conductivity in the extracts of the manure, sludge and municipal solid waste amendments were as high as $17,9.4$ and $14.7 \mathrm{dS} \mathrm{m}^{-1}$, respectively.

The amount of SOC in soil was influenced by the type of amendments. The SOC content was generally greater in the amended soils compared to the control however, the greatest SOC content was observed in the sewage sludge treatment (Table 2 ). The activity of $\beta$ glucosidase was similarly increased in amended soils compared to the control but the maximum $\beta$ glucosidase activity was observed in the soil treated with cow manure (Table 2).

The activity of $\beta G$ as compared to control treatment reached a maximum by increasing level of organic fertilizer application from 25-100 $\mathrm{Mg} \mathrm{ha}{ }^{-1}$ (Table 3). The highest level of SOC was observed in the soils received $100 \mathrm{Mg} \mathrm{ha}^{-1}$ of the amendments. Soils with 50 and $25 \mathrm{Mg} \mathrm{ha}^{-1}$ application rates came in the next orders, respectively (Table 3 ). 
Am. J. Agri. \& Biol. Sci., 4 (3): 179-186, 2009

Table 1: Chemical characteristics of the organic amendments

\begin{tabular}{llccc}
\hline & Unit & $\begin{array}{l}\text { Sewage } \\
\text { sludge }\end{array}$ & $\begin{array}{l}\text { Cow } \\
\text { manure }\end{array}$ & $\begin{array}{l}\text { Municipal } \\
\text { solid waste }\end{array}$ \\
\hline $\mathrm{pH}$ & - & 6.40 & 8.60 & 7.80 \\
${ }^{\mathrm{a}} \mathrm{EC}$ & $\left(\mathrm{dS} \mathrm{m}_{\mathrm{e}}\right.$ & 9.40 & 17.00 & 14.70 \\
${ }^{\mathrm{b}} \mathrm{SOC}$ & $\left(\mathrm{g} \mathrm{kg}^{-1}\right)$ & 310.00 & 430.00 & 270.00 \\
${ }^{\mathrm{c}} \mathrm{Pb}$ & $\left(\mathrm{m} \mathrm{kg}^{-1}\right)$ & 148.50 & 20.50 & 113.00 \\
${ }^{\mathrm{c}} \mathrm{Ni}$ & $\left(\mathrm{m} \mathrm{kg} \mathrm{k}^{-1}\right)$ & 48.00 & 12.50 & 56.00 \\
${ }^{\mathrm{c}} \mathrm{Zn}$ & $\left(\mathrm{m} \mathrm{kg} \mathrm{k}^{-1}\right)$ & 217.00 & 82.50 & 710.00 \\
${ }^{\mathrm{c}} \mathrm{Cu}$ & $\left(\mathrm{mg} \mathrm{kg}^{-1}\right)$ & 159.50 & 39.50 & 130.00 \\
\hline
\end{tabular}

${ }^{a}$ : Electrical conductivity; ${ }^{b}$ : Soil organic $\mathrm{C} ;^{\mathrm{c}}{ }^{\mathrm{c}}$ : DTPA-extractable

Table 2: Soil Organic Carbon (SOC) and $\beta$-Glucosidase ( $\beta \mathrm{G})$ activity as affected by type of amendments

\begin{tabular}{lll}
\hline Type of amendments & SOC $\left(\mathrm{g} \mathrm{kg}^{-1}\right)$ & $\beta \mathrm{G}\left(\mathrm{mg} \mathrm{PNP} \mathrm{kg}^{-1}\right.$ soil h$\left.^{-1}\right)$ \\
\hline CM & $20.70 \mathrm{~b}$ & $472.70 \mathrm{a}$ \\
SS & $22.20 \mathrm{a}$ & $232.91 \mathrm{c}$ \\
MSW & $16.80 \mathrm{c}$ & $326.65 \mathrm{~b}$ \\
control & $9.23 \mathrm{~d}$ & $182.77 \mathrm{~d}$
\end{tabular}

CM: Cow Manure, SS: Sewage Sludge, MSW: Municipal Solid Waste; Different letters in each column indicate significant difference between treatments according to Duncan test $(\mathrm{p}<0.05)$

Table 3: Soil Organic Carbon (SOC) and $\beta$-glucosidase ( $\beta \mathrm{G})$ activity as affected by application rates

\begin{tabular}{lll} 
Level of application & SOC $\left(\mathrm{g} \mathrm{kg}^{-1}\right)$ & $\beta \mathrm{G}\left(\mathrm{mg} \mathrm{PNP} \mathrm{kg}{ }^{-1}\right.$ soil h$\left.^{-1}\right)$ \\
\hline $100\left(\mathrm{Mg} \mathrm{ha}^{-1}\right)$ & $29.30 \mathrm{a}$ & $489.94 \mathrm{a}$ \\
$50\left(\mathrm{Mg} \mathrm{ha}^{-1}\right)$ & $22.67 \mathrm{~b}$ & $385.19 \mathrm{~b}$ \\
$25\left(\mathrm{Mg} \mathrm{ha}^{-1}\right)$ & $18.55 \mathrm{c}$ & $318.45 \mathrm{c}$ \\
Control & $9.23 \mathrm{~d}$ & $182.77 \mathrm{~d}$ \\
\hline
\end{tabular}

Different letters in each column indicate significant difference between treatments according to Duncan test $(\mathrm{p}<0.05)$

The distribution of aggregate size classes was influenced by application of the organic amendments (Fig. 1). Microaggregates $(<0.25 \mathrm{~mm})$ consisted $64 \%$ of the control soil while the percentage has been decreased to 35,39 and $42 \%$ in MSW, SS and CM, respectively. No significant differences were observed among macroaggregate $(>0.25 \mathrm{~mm})$ classes in control treatment. It was also observed that in soils treated with SS, CM and MSW, there were no differences in distribution of macroaggregate size classes (Fig. 1). However, the contribution of the largest macroaggregates (size $>2 \mathrm{~mm}$ ) in control and sewage sludge-amended soils were 2 and $13 \%$, respectively. In $\mathrm{CM}$ and MSW, the percentage of microaggregates and the smallest macroaggregate size class $(0.25-0.5 \mathrm{~mm})$ were not significantly different. An increasing trend was observed for macroaggregate formation as level of organic fertilizer application increased (Fig. 2).

When the distribution of $\beta \mathrm{G}$ activity was weighed to the contribution of aggregate fractions in each soil (aggregate-derived activity), all organic amended soils had approximately similar pattern of activity distributions within aggregate size fractions,

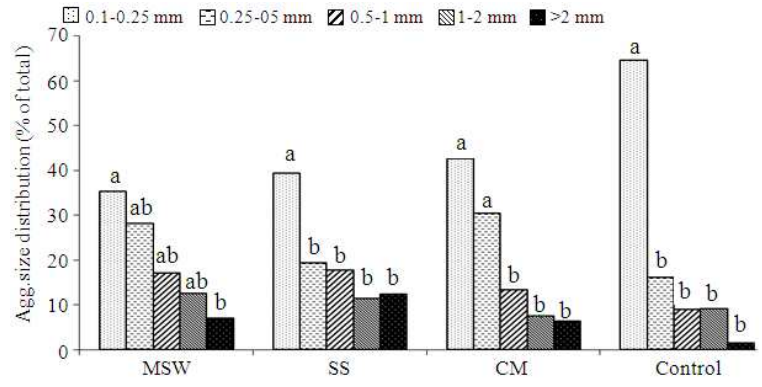

Fig. 1: Aggregate size distribution in soils received Cow Manure (CM), Sewage Sludge (SS), Municipal Solid Wastes (MSW). Bars topped with the same letter within each type of treatments are not significantly different $(\mathrm{p}<0.005)$

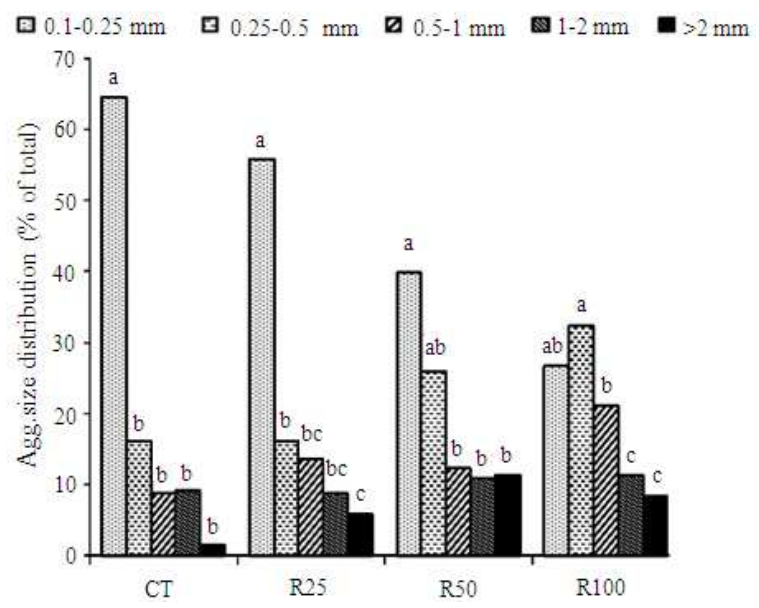

Fig. 2: Aggregate size distribution in soils received different rates of organic amendments. Bars topped with the same letter within each rate of applications are not significantly different $(\mathrm{p}<0.005)$

though $\beta G$ activity in sludge amended soils were consistently lower (Fig. 3a). The SOC contents in macroaggregates were consistently greater than in that of microaggregates. The pattern was somehow similar in all treatments (Fig. 3b). The greatest rates of $\beta G$ activity found in the macroaggregate size classes which also possessed higher amount of SOC (Table 4). While the $\beta G$ activity among the macroaggregate size classes was not significantly different, application of amendments in various rates resulted in considerable differences among the classes (Fig. 4a). The SOC contents in the aggregate size classes have been increased proportionally as the rate of application increased (Fig. 4b). 
Table 4: Soil Organic Carbon (SOC) and $\beta$-Glucosidase ( $\beta$ G) activity as affected by aggregate size fraction

\begin{tabular}{lll}
\hline Aggregate size fraction & SOC $\left(\mathrm{g} \mathrm{kg}^{-1}\right)$ & $\beta \mathrm{G}\left(\mathrm{mg} \mathrm{PNP} \mathrm{kg}{ }^{-1} \mathrm{soil} \mathrm{h}^{-1}\right)$ \\
\hline$>2 \mathrm{~mm}$ & $23.48 \mathrm{a}$ & $463.67 \mathrm{a}$ \\
$1-2 \mathrm{~mm}$ & $22.83 \mathrm{a}$ & $350.95 \mathrm{~b}$ \\
$0.5-1.0 \mathrm{~mm}$ & $22.69 \mathrm{a}$ & $374.18 \mathrm{c}$ \\
$0.25-0.5 \mathrm{~mm}$ & $19.76 \mathrm{~b}$ & $341.18 \mathrm{~d}$ \\
$0.1-0.25 \mathrm{~mm}$ & $10.94 \mathrm{c}$ & $190.47 \mathrm{c}$ \\
\hline
\end{tabular}

Different letters in each column indicate significant difference between treatments according to Duncan test $(\mathrm{p}<0.05)$

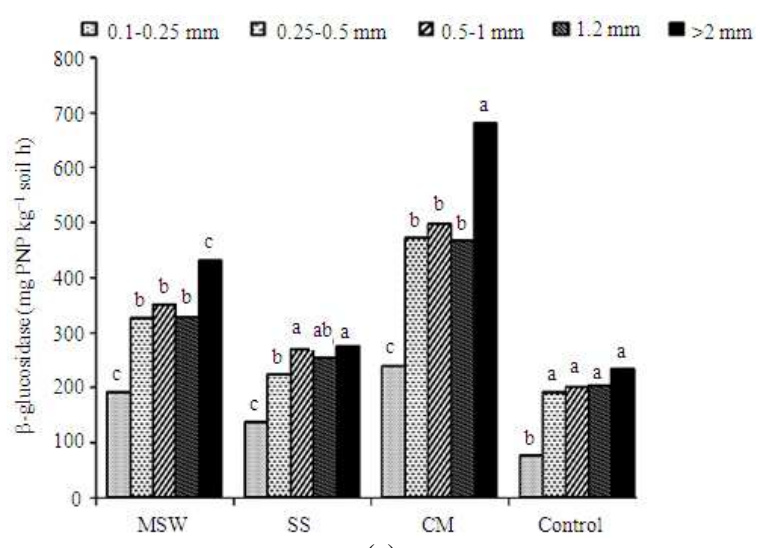

(a)

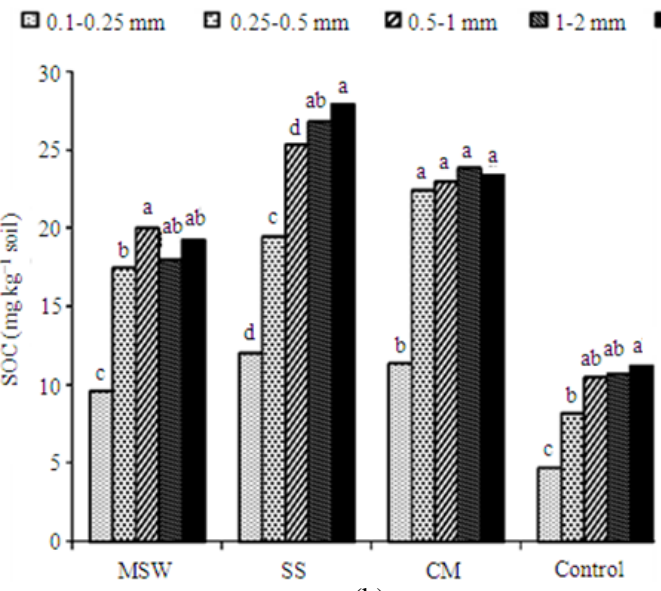

(b)

Fig. 3: $\beta$-glucosidase activity (a) and Soil Organic Carbon (SOC) content (b) of each aggregate size classes in soils received different type of amendments. Bars topped with the same letter within each type of treatments are not significantly different $(\mathrm{p}<0.05)$

\section{DISCUSSION}

Although the sewage sludge is mildly acidic, the high content of $\mathrm{Ca}$-carbonate equivalent in the soil (395.3 $\mathrm{g} \mathrm{kg}^{-1}$ ) creates high buffering capacity. Hence,

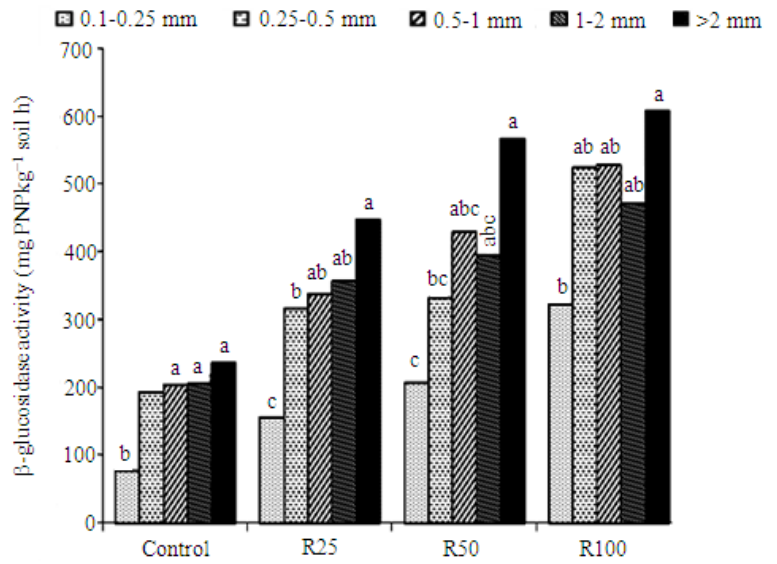

(a)

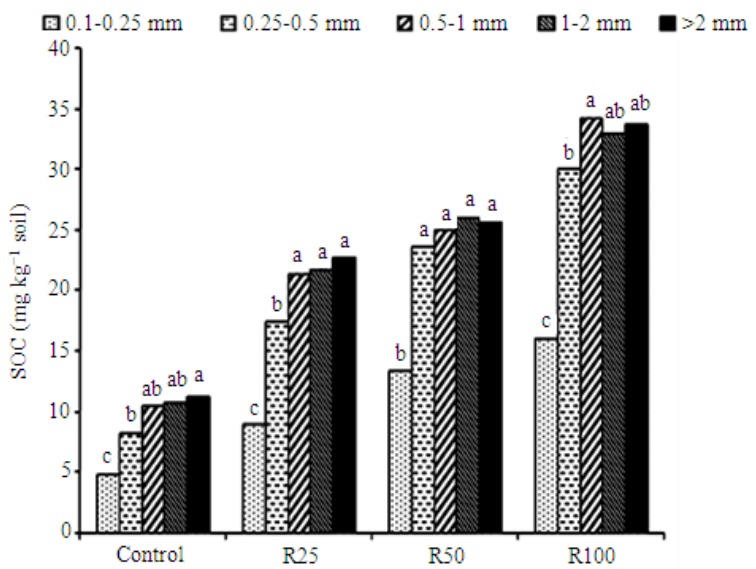

(b)

Fig. 4: $\beta$-glucosidase activity (a) and Soil Organic Carbon (SOC) content (b) of each aggregate size classes in soils received different rates of organic amendments. Bars topped with the same letter within each rate of applications are not significantly different $(\mathrm{p}<0.05)$

$\mathrm{pH}$ values were not significantly changed even in the soil treated annually with highest rate of organic amendments. The high values of electrical conductivity particularly in manure and municipal solid wastes had the potential to cause salinity problems in the applied soils. However, the field was under surface irrigation and therefore, the electrical conductivity of the soils remained in the same order of magnitude because of regular leaching of excessive soluble salts by irrigation water (data not shown).

Higher levels of SOC were observed in soils received organic amendments compared to control (Table 2). As expected, SOC content of the soils enhanced as the rate of application increased. The 
increased levels of SOC in organic fertilizer treated soils compared to control (Table 1) were attributed to the higher input of organic $\mathrm{C}^{[14]}$. Similarly, composted manure applications up to $45 \mathrm{Mg} \mathrm{ha}^{-1}$ year $^{-1}$ for 2 years increased SOC and led to more wet stable aggregates $>2 \mathrm{~mm}$ in conventional tillage and no tillage systems $^{[15]}$.

$\beta$-glucosidase activity reflects the state of the organic matter and the processes occurring therein ${ }^{[16]}$. The enzyme activity was low in the control treatment (Table 2), probably due to the low organic carbon content of arid soils ${ }^{[1]}$. Application of organic amendments to this soil had a positive influence on the activity of this enzyme and soil amended with $\mathrm{CM}$ was responsible for the highest values observed for $\beta G$ activity (Table 2 ). The greater $\beta \mathrm{G}$ activity of the $\mathrm{CM}$ compared to the SS and MSW can partially be attributed to the greater heavy metal concentrations in the sewage sludge and the municipal solid wastes (Table 1). Enhanced enzyme activities after long-term application of farmyard manures have been reported ${ }^{[17]}$. The study has shown that manure-amended soils have higher microbial biomass, $\mathrm{N}$ mineralization potential and microbial activities that are related to some enzymatic activities. This would be expected as elevated levels of $\mathrm{C}$ inputs and other nutrients would stimulate biological activity and stabilization of abiontic enzymes ${ }^{[17]}$. The activity of soil enzymes may be inhibited by using a certain kind of organic amendments. It has been reported that the presence of heavy metals in sewage sludge were responsible for the inhibitory effects when amended soils were assayed for urease and phosphatase activity ${ }^{[18]}$. The activity of $\beta G$ as compared to control treatment reached a maximum by increasing level of organic fertilizer application from 25-100 Mg ha ${ }^{-1}$ (Table 3). This implies that environmental conditions created by $100 \mathrm{Mg} \mathrm{ha}^{-1}$ were likely to be more favorable to the growth of microorganisms and plant roots that secrete this enzyme into the soil. The level of soil enzyme activity increases with increasing soil organic matter content ${ }^{[19]}$.

Our results indicated that macroaggregates frequency have been enhanced in all amended soils however, distribution pattern of various macroaggregates in amended soils are dissimilar (Fig. 1). Different chemical properties of organic carbon in the amendments can influence the response of aggregation ${ }^{[20]}$. It has been reported that different macroaggregate distribution patterns were observed, when native prairie, cultivated and two restoration treatments were compared ${ }^{[9]}$. It seems that, management practices (either organic fertilization or restoration practices) which improve SOC status, can also affect the aggregate size distribution.
An increasing trend was observed for macroaggregate formation as level of organic fertilizer application increased (Fig. 2). It has been suggested that organic $\mathrm{C}$ provided from higher application rates would stimulate aggregation through increased SOC as hot spots for aggregation and increased biological activity $^{[21]}$.

All amended soils exhibited larger amounts of $\beta G$ aggregate-derived activity in the $>2 \mathrm{~mm}$ size fraction (Fig. 3a). The greater level of $\beta G$ activity of macroaggregate size fractions in CM, SS and MSW compared to the control treatment was likely adapting to the changes caused by the organic amendments application. This was also the case when distribution of SOC and $\beta \mathrm{G}$ activity were compared in different levels of application (Fig. 4a and b). Nutrient management through chemical fertilization and manure applications generally increases aggregation, SOC concentration and microbial communities ${ }^{[21,22]}$. These workers concluded that the primary effect of improved nutrient management is on increasing plant productivity, SOC and soil biological activity. It is probable that microbial communities were responding to an increase in soil organic matter due to application of organic amendments (Fig. 3b). This agrees with other studies that likewise concluded that macroaggregate structures provide habitat for microbial biomass and enzyme activity ${ }^{[23,24]}$. The varying predominance of the individual enzymes in the different aggregate size fractions can be discussed on the basis of the location of soil microorganisms and their substrates ${ }^{[25]}$. The activity of $\beta \mathrm{G}$, which is produced and released to a great extent by both bacteria and fungi ${ }^{[12]}$ was mainly found in the largest aggregate size classes (Fig. 3a). The high $\beta G$ activity (Fig. 3a) and the high SOC content (Fig. 3b) of the largest aggregate size fractions indicated that this enzyme is mainly bound to and stabilized by particulate organic matter ${ }^{[25]}$. The organic amendments increased the capacity of macroaggregates to protect $\beta G$ activity in amended soils.

Although the size fraction of $0.1-0.25 \mathrm{~mm}$ exhibited the greatest contribution in all treatments (Fig. 1 and 2), but showed the lowest level of SOC content. Similarly, Elliot ${ }^{[6]}$ observed more organic matter associated with macroaggregates than with microaggregates in a temperate grassland soil.

As SOC content enhanced by application of organic amendments (Table 2 and 3), the abundance of $0.1-0.25 \mathrm{~mm}$ size classes decreased and instead, the frequency of larger aggregate size classes increased (Fig. 1 and 2). The increased contribution of the size class $>2 \mathrm{~mm}$ is consistent with increasing SOC content. This result was in line with the concept of aggregate 
hierarchy according to which microaggregates are bound together into macroaggregates by transient and temporary binding agents ${ }^{[26]}$. The consequences of this aggregate hierarchy are an increase in $\mathrm{C}$ concentration with increasing aggregate-size classes because larger aggregate-size classes are composed of smaller aggregate size classes and organic binding agents ${ }^{[26]}$

In the current study, the greatest rates of $\beta G$ activity found in the macroaggregate size classes which also possessed higher amount of SOC (Table 4). It is suggested that macroaggregates would contain more labile carbon and microaggregates possessed more recalcitrant carbon ${ }^{[6]}$. Results obtained by Gupta and Germida $^{[23]}$ showed that there are greater concentrations of organic $\mathrm{C}$ in macroaggregates than in microaggregates. Greater mineralization of intramacroaggregate organic matter compared with those associated with microaggregates was also reported $^{[23]}$. We observed that the lowest SOC contents were found to be in aggregate fraction $<0.25 \mathrm{~mm}$. One possible interpretation is that this fraction contained sand particles and free silt particles and it might be that the low SOC content in this fraction was influenced by the accumulation of free silt particles with low or no binding capacity of $\mathrm{SOC}^{[27]}$.

The microaggrgate fraction did not contribute much to the $\beta \mathrm{G}$ activity of the whole soils (Fig. 3a and 4a and Table 4), because this fraction is poor in SOC content and therefore, provides lower level of $\beta G$ activity in all amended soils. It can be relevant to the fact that bonds within microaggregates are stronger than bonds between microaggregates and therefore be protected more from decomposition ${ }^{[28]}$. It is also possible that residual enzyme activity was protected in these microaggregates by having been once incorporated into larger macroaggregate structure. Evidence for this conclusion is supported by the carbon stable isotope data ${ }^{[7]}$ in which the age of $\mathrm{C} 3$ and $\mathrm{C} 4$ derived $\mathrm{C}$ in aggregate size fractions of pasture and cultivated (corn) soils was compared. The larger macroaggregates were found to have a greater proportion of recently deposited $\mathrm{C}$ and thus a more rapid apparent turnover rate (74 years) than that of the microaggregate structures (412 years) ${ }^{[7]}$.

\section{CONCLUSION}

In summary, CM, MSW and SS influenced SOC in a direction that is compatible with improved soil aggregation. The application of solid wastes is a suitable method for recovering structure of soils in arid areas. After the seventh year onward, the incorporation of amendments seems to be effective on maintenance of carbon cycle and through which $\mathrm{CM}$ was the most effective amendment. Application of organic amendments was observed to be effective in increasing the distribution of macroaggregates to microaggregate size classes when compared with control treatment. The highest and lowest proportion of macroaggregates was shown in MSW and control treatments. The greatest value of $\beta G$ activity was observed in size classes of $>2 \mathrm{~mm}$ in $\mathrm{CM}$. An increasing trend was observed in macroaggregates proportion as level of organic amendments application increased. This implies that hierarchical theory of aggregation can be thought as the main mechanism for aggregate formation in this study. The highest activities of $\beta \mathrm{G}$ and SOC contents were observed in macroaggregates and in soils received the highest rates of organic fertilizer applications. This implies that macroaggregate formation modified the distribution of SOC and $\beta \mathrm{G}$ activity.

\section{ACKNOWLEDGMENT}

The researchers gratefully acknowledge Soil Science Center of Excellences, Isfahan University of Technology for funding the project.

\section{REFERENCES}

1. Garcia, C., T. Hernández and A. Roldán, 1997. Changes in microbial activity after abandonment of cultivation in a semiarid Mediterranean environment. J. Environ. Qual., 26: 285-291. http://cat.inist.fr/?aModele=afficheN\&cpsidt=2580689

2. Roldán, A., F. Caravaca, M. T. Hernández, C. Garcia, C. Sánchez-Brito, M. Velásquez and M. Tiscareno, 2003. No-tillage, crop residue additions and legume cover cropping effects on soil quality characteristics under maize in Patzcuaro watershed (Mexico). Soil Till. Res., 72: 65-73. DOI: 10.1016/S0167-1987(03)00051-5

3. Chantigny, M.H., D.A. Angers and C.J. Beauchamp, 2000. Active carbon pools and enzyme activities in soils amended with de-inking paper slurry. Can. J Soil Sci., 80: 99-105. DOI: 10.4141/S99-050

4. Martens, D.A., 2000. Management and crop residue influence soil aggregate stability. J. Environ. Qual., 29: 723-727. http://cat.inist.fr/?aModele $=$ afficheN\&cpsidt $=1416008$

5. Chan, K.Y., D.P. Heenan and H.B. So, 2003. Sequestration of carbon and changes in soil quality under conservation tillage on light textured soils in Australia: A review. Aus. J. Exp. Agron., 43: 325-334. http://cat.inist.fr/?aModele $=$ afficheN\&cpsidt $=1484$ 7736 
6. Elliott, E.T., 1986. Aggregate structure and carbon, nitrogen and phosphorus in native and cultivated soils. Soil Sci. Soc. Am. J., 50: 627-633. http://soil.scijournals.org/cgi/content/abstract/50/3/ 627

7. Jastrow, J. D., T.W. Boutton and R.M. Miller, 1996. Carbon dynamics of aggregate-associated organic matter estimated by carbon-13 natural abundance. Soil Sci. Soc. Am. J., 60: 801-807. http://cat.inist.fr/?aModele $=$ afficheN\&cpsidt $=3092$ 216

8. Puget, P., C. Chenu and J. Balesdent, 1995. Total and young organic matter distributions in aggregates of silty cultivated soils. Eur. J. Soil Sci., 46: 449-459.

http://cat.inist.fr/?aModele $=$ afficheN\&cpsidt=2891 126

9. Fansler, S.J., J.L. Smith, H. Bolton and V.L. Baily Jr., 2005. Distribution of two C cycle enzymes in soil aggregates of a prairie chronosequence. Biol. Fertil. $\quad$ Soils., $\quad 42$ 17-23. http://cat.inist.fr/?aModele $=$ afficheN\&cpsidt $=1748$ 4979

10. Debosz, K., P.H. Rasmussen and A.R. Pedersen, 1999. Temporal variations in microbial biomass $C$ and cellulolytic enzyme activity in arable soils: Effects of organic matter input. Applied Soil Ecol., 13: 209-218. DOI: $10.1016 /$ S09291393(99)00034-7

11. Hesse, P.R., 1972. A Textbook of Soil Chemical Analysis. John Murray, London, ISBN: 0820602424, pp: 556.

12. Tabatabai, M.A., 1994. Soil Enzymes. In: Methods of Soil Analysis, Part 2, Microbiological and Biochemical Properties, Weaver, R.W., J.S. Angel and P.S. Bottomley (Eds.). Soil Science Society of America, Madison, WI., USA., ISBN: 10: 089118810X, pp: 775-833.

13. Cody, R., 2007. Learning SAS by Examples: A Programmers Guid. SAS Institute Inc., Cary, NC., ISBN: 978-1-59994-165-3, pp: 80-135.

14. Oades, J.M., 1984. Soil organic matter and structural stability: Mechanisms and implications for management. Plant Soil, 76: 319-337. DOI: 10.1007/BF02205590

15. Whalen, J.K., Q. Hu and A. Liu, 2003. Manure applications improve aggregate stability in conventional and no-tillage systems. Soil Sci. Soc. Am. J., 67: 1842-1847. http://soil.scijournals.org/cgi/content/full/67/6/1 842
16. Garcia, C., T. Hernández, F. Costa and B. Ceccanti, 1994. Biochemical parameters in soils regenerated by the addition of organic wastes. Waste Manage. Res., 12: 457-466. http://cat.inist.fr/?aModele $=$ afficheN $\&$ cpsidt $=3551$ 315

17. Kandeler, E and G. Eder, 1993. Effects of cattle slurry in grassland on microbial biomass and on activities of various enzymes. Biol. Fertil. Soils, 16: 249-254.

http://cat.inist.fr/?aModele $=$ afficheN\&cpsidt $=4916$ 682

18. Bonmati, M., H. Pujola, J. Sana, J. Soliva, M.T. Felipo, M. Garau, B. Ceccanti and P. Nannipieri, 1985. Chemical properties, population of nitrige oxidizers, urease and phosphatase activities in sewage sludge amended soil. Plant Soil. 84: 79-91. DOI: 10.1007/BF02197869

19. Speir, T.W., 1977. Studies on a Climosequence of Soils in Tussock Grasslands. II. Urease, phosphatase and sulfatase activities of topsoils and their relationships with other properties including plant available sulfur. N. Z. J. Sci., 20: 159-166. http://www.fao.org/agris/search/display.do?f=./197 8/v403/NZ7801105.xml;NZ7801105

20. Schluten, H.R. and P. Leinweber, 2000. New insights into organic-mineral particles: Composition, properties and models of molecular structure. Biol. Fertil. Soils, 30: 399-432. http://cat.inist.fr/?aModele $=$ afficheN\&cpsidt $=1454$ 762

21. Aoyama, M., D.A. Angers, A. N'Dayegamiye and N. Bissonnette, 2000. Metabolism of C-13-labeled glucose in aggregates from soils with manure application. Soil Biol. Biochem., 32: 295-300. http://cat.inist.fr/?aModele=afficheN\&cpsidt=1307 952

22. Haynes, R.J. and R. Naidu, 1998. Influence of lime, fertilizer and manure applications on soil organic matter content and soil physical conditions: A review. Nutr. Cycl. Agroecosyst., 51: 123-137. http://cat.inist.fr/?aModele $=$ afficheN\&cpsidt $=1045$ 3678

23. Gupta, V.V.S.R. and J.J. Germida, 1988. Distribution of microbial biomass and its activity in different soil aggregate size classes as affected by cultivation. Soil Biol. Biochem., 20: 777-786. http://cat.inist.fr/?aModele $=$ afficheN\&cpsidt $=7163037$

24. Miller, M. and R.P. Dick, 1995. Thermal stability and activities of soil enzymes as influenced by crop rotations. Soil Biol. Biochem., 27: 1161-1166. http://cat.inist.fr/?aModele $=$ afficheN\&cpsidt $=3621$ 188 
25. Kandeler, E., M. Stemmerand and E.M. Klimanek, 1999. Response of soil microbial biomass, urease and xylanase within particle size fractions to longterm soil management. Soil Biol. Biochem., 31: 261-273. http://cat.inist.fr/?aModele $=$ afficheN\&cpsidt $=1700$ 383

26. Six, J., K. Paustian, E. T. Elliott and C. Combrink, 2000. Soil structure and organic matter: I. Distribution of aggregate-size classes and aggregate-associated carbon. Soil Sci. Soc. Am. J., 64: 681-689.

http://cat.inist.fr/?aModele $=$ afficheN\&cpsidt=1489 569
27. John, B., T. Yamashita, B. Ludwig and H. Flessa, 2005. Storage of organic carbon in aggregates and density fraction of silty soils under different types of land use. Geoderma, 128: 63-79. http://cat.inist.fr/?aModele $=$ afficheN\&cpsidt $=1698$ 3146

28. Bronick, C.J. and R. Lal, 2005. Soil structure and management: A review. Geoderma, 124: 3-22. http://cat.inist.fr $/$ ?aModele $=$ afficheN\&cpsidt $=1642$ 5818 